\title{
Letter to the editor: A response to the comments of Silanikove et al. (2015)
}

\author{
T. Tomazi, J. L. Gonçalves, J. R. Barreiro, M. A. Arcari, and M. V. dos Santos ${ }^{1}$ \\ Department of Animal Nutrition and Production, School of Veterinary Medicine and Animal Science, University of São Paulo, \\ Pirassununga 13635-900, Brazil
}

We very much appreciate the interest in our recent publication "Bovine subclinical intramammary infection caused by coagulase-negative staphylococci increases somatic cell count but has no effect on milk yield and composition" (Tomazi et al., 2015).

In reference to the comments, Silanikove and colleagues (2015) first raised concerns about the implication of our results, which showed that at the quarter level, IMI caused by CNS increased the SCC of milk, but had no effect on milk composition and yield of dairy cows. In their comments, they expressed concern that "adoption of the implication of this study might be associated with dissemination of an erroneous concept regarding the importance of CNS infection..."

Then, Silanikove et al. (2015) questioned our assumption that "no previous studies reported the effect of IMI caused by CNS on milk yield and composition by comparison of contralateral mammary quarters." Three papers (Leitner et al., 2006, 2011; Silanikove et al., 2014b) were cited to support their contention and they declared that, based on these studies, IMI caused by CNS had a significant effect on milk composition; specifically, on casein and lactose concentrations. They also observed that IMI caused by CNS had a negative effect on "milk clotting parameters as reflected by lower curd firmness and increased rennet clotting time, consistent with similar findings in goats and sheep."

Silanikove et al. (2015) also indicate that "it should be noted that mixing bacterially contaminated milk with milk from noncontaminated glands negatively affects the clotting parameters of the uninfected milk" according to Silanikove et al. (2014a) and Leitner et al. (2008).

In response to the first comment, and as described in our study, "the effect of IMI caused by CNS on milk yield and composition remains inconclusive." Therefore, it would be no surprise to find studies reporting

\footnotetext{
Received August 1, 2015.

Accepted August 4, 2015.

${ }^{1}$ Corresponding author: mveiga@usp.br
}

different trends in terms of the effect of IMI caused by CNS on milk yield and composition. The possible reasons for these differences in results were also described in our paper: "The variability among studies on the effect of CNS on milk yield and composition might be attributed to differences in study design and challenge conditions." (Tomazi et al., 2015; page 3071)

Our results are consistent with other studies (Kirk et al., 1996; Paradis et al., 2010; Pearson et al., 2013; Hertl et al., 2014; Silanikove et al., 2014b), which also reported no effect of IMI caused by CNS on milk yield in dairy cows. Effect of CNS IMI on milk production of dairy cows was not observed even when comparing monozygotic twins (Pearson et al., 2013). In addition, we should consider that some studies have reported higher milk production in cows with IMI caused by CNS relative to that of uninfected cows (Schukken et al., 2009; Piepers et al., 2010, 2013), which might be attributed to a protective effect of pre-existing CNS IMI against more-virulent mastitis pathogens. Thus, considering these recent published studies and the considerable number of contralateral mammary quarters evaluated in our study, we still consider that our conclusion that IMI caused by CNS did not alter milk yield and gross milk composition of dairy cows is correct and not an "erroneous concept."

In response to the second comment, according to Leitner et al. (2006), based on a limited number of bovine mammary quarters for evaluation of milk composition (11 mammary quarters infected by Staphylococcus chromogenes vs. 33 uninfected quarters), the results indicated no difference between infected and uninfected quarters relative to fat, protein, and lactose concentrations. It should be noted that, according to Leitner et al. (2006), lactose contents were statistically similar between uninfected $\left(144 \pm 3^{\mathrm{a}} \mathrm{m} M\right)$ and infected quarters $\left(140 \pm 6^{\mathrm{a}, \mathrm{b}} \mathrm{m} M\right)$. Similar results on gross milk composition were also reported by Silanikove et al. (2014b). As described in Table 2 of Silanikove et al. (2014b), at the gland level, IMI caused by CNS had no effect of on fat, protein, or lactose contents when comparing uninfected and infected quarters. The lactose contents reported in the latter study were $50.2 \pm 2.4^{\mathrm{a}} \mathrm{g} / \mathrm{L}$ for 
uninfected quarters and $47 \pm 2.4^{\mathrm{ab}} \mathrm{g} / \mathrm{L}$ for infected quarters. Despite the fact that our study showed no effect of IMI caused by CNS on lactose content, in the discussion section of our study, we noted that lactose concentration might be a sensitive parameter in the presence of IMI caused by CNS. Nevertheless, our main objective was to evaluate the effect of IMI caused by CNS on milk yield and gross milk composition, and we conducted no evaluation of the contents of casein or of milk-clotting parameters. Therefore, in our opinion, because of design differences, comparisons between these studies are very difficult and prone to erroneous conclusions.

In response to the third comment, the assumption that "mixing bacterially contaminated milk with milk from noncontaminated glands negatively affects the clotting parameters of the uninfected milk," cannot be addressed in the context of our study, because it was not our objective to evaluate these milk quality parameters.

Finally, Silanikove et al. (2015) concluded that "The lack of significant reduction in milk yield results from dilution of the lesser yield of a single gland and compensation of milk yield increase by the other uninfected glands (Silanikove et al., 2014a,b)." However, the interdependence of infections, inflammatory processes, and immune responses in individual udder quarters is discussed controversially in the literature. Some authors suggest that individual udder quarters within a cow can be influenced by infections of neighboring quarters (Merle et al., 2007), whereas others have found no evidence for the interdependence of udder quarters (Wever and Emanuelson, 1989) because differential cell counts were not affected by the bacteriological status of adjacent quarters. The determination of different types of immune cells present in milk is beneficial for describing udder health status (Pilla et al., 2012). Recently, Schwarz et al. (2011) observed no immunological interdependence between the 4 udder quarters at low and high SCC levels, suggesting that there is no compensatory effect of milk yield and composition from uninfected quarters when the udder has an infected quarter.

In conclusion, considering that the papers cited by Silanikove and colleagues (Leitner et al., 2006, 2011; Silanikove et al., 2014b) to support the negative effect of the IMI caused by CNS on gross milk composition at the quarter level, specifically fat, protein, and lactose, in fact reported no significant differences in terms of gross milk composition, we disagree that the implications of our results (Tomazi et al., 2015) could stimulate the "dissemination of an erroneous concept regarding the importance of CNS infection in dairy cow husbandry." As a final remark, it is notable that, in the discussion section of Tomazi et al. (2015), despite finding no effect of IMI caused by CNS on milk yield and composition, we raised awareness about the importance of controlling subclinical CNS IMI: "... because of the high prevalence of CNS in modern dairy herds, the potential to cause persistent infection, antibiotic resistance, and significant increases in SCC efforts should be monitored to reduce the prevalence of this group of pathogens in dairy herds."

\section{REFERENCES}

Hertl, J. A., Y. H. Schukken, F. L. Welcome, L. W. Tauer, and Y. T. Grohn. 2014. Pathogen-specific effects on milk yield in repeated clinical mastitis episodes in Holstein dairy cows. J. Dairy Sci. 97:1465-1480.

Kirk, J. H., J. C. Wright, S. L. Berry, J. P. Reynolds, J. P. Maas, and A. Ahmadi. 1996. Relationships of milk culture status at calving with somatic cell counts and milk production of dairy heifers during early lactation on a Californian dairy. Prev. Vet. Med. 28:187-198.

Leitner, G., O. Krifucks, U. Merin, Y. Lavi, and N. Silanikove. 2006. Interactions between bacteria type, proteolysis of casein and physico-chemical properties of bovine milk. Int. Dairy J. 16:648-654.

Leitner, G., U. Merin, and N. Silanikove. 2011. Effects of glandular bacterial infection and stage of lactation on milk clotting parameters: Comparison among cows, goats and sheep. Int. Dairy J. 21:279-285. http://dx.doi.org/10.1016/j.idairyj.2010.11.013.

Leitner, G., N. Silanikove, S. Jacobi, L. Weisblit, S. Bernstein, and U. Merin. 2008. The influence of storage on the farm and in dairy silos on milk quality for cheese production. Int. Dairy J. 18:109-113.

Merle, R., A. C. Schröder, and J. Hamann. 2007. Cell function in the bovine mammary gland: A preliminary study on interdependence of healthy and infected udder quarters. J. Dairy Res. 74:174-179.

Paradis, M. E., E. Bouchard, D. T. Scholl, F. Miglior, and J. P. Roy. 2010. Effect of nonclinical Staphylococcus aureus or coagulasenegative staphylococci intramammary infection during the first month of lactation on somatic cell count and milk yield in heifers. J. Dairy Sci. 93:2989-2997.

Pearson, L. J., J. H. Williamson, S. A. Turner, S. J. Lacy-Hulbert, and J. E. Hillerton. 2013. Peripartum infection with Streptococcus uberis but not coagulase-negative staphylococci reduced milk production in primiparous cows. J. Dairy Sci. 96:158-164.

Piepers, S., G. Opsomer, H. W. Barkema, A. de Kruif, and S. De Vliegher. 2010. Heifers infected with coagulase-negative staphylococci in early lactation have fewer cases of clinical mastitis and higher milk production in their first lactation than noninfected heifers. J. Dairy Sci. 93:2014-2024.

Piepers, S., Y. H. Schukken, P. Passchyn, and S. De Vliegher. 2013. The effect of intramammary infection with coagulase-negative staphylococci in early lactating heifers on milk yield throughout first lactation revisited. J. Dairy Sci. 96:5095-5105.

Pilla, R., D. Schwarz, S. Konig, and R. Piccinini. 2012. Microscopic differential cell counting to identify inflammatory reactions in dairy cow quarter milk samples. J. Dairy Sci. 95:4410-4420.

Schukken, Y. H., R. N. Gonzalez, L. L. Tikofsky, H. F. Schulte, C. G. Santisteban, F. L. Welcome, G. J. Bennett, M. J. Zurakowski, and R. N. Zadoks. 2009. CNS mastitis: Nothing to worry about? Vet. Microbiol. 134:9-14.

Schwarz, D., U. S. Diesterbeck, S. Konig, K. Brugemann, K. Schlez, M. Zschock, W. Wolter, and C. P. Czerny. 2011. Microscopic differential cell counts in milk for the evaluation of inflammatory reactions in clinically healthy and subclinically infected bovine mammary glands. J. Dairy Res. 78:448-455.

Silanikove, N., U. Merin, and G. Leitner. 2015. Letter to the editor: Do coagulase-negative staphylococci have no effect on the milk 
composition of infected mammary gland? A comment on Tomazi et al. (2015). J. Dairy Sci. 98:7421-7422.

Silanikove, N., U. Merin, F. Shapiro, and G. Leitner. 2014a. On effects of subclinical mastitis and stage of lactation on milk quality in goats. Small Rumin. Res. 122:76-82.

Silanikove, N., U. Merin, F. Shapiro, and G. Leitner. 2014b. Milk metabolites as indicators of mammary gland functions and milk quality. J. Dairy Res. 81:358-363.

Tomazi, T., J. L. Gonçalves, J. R. Barreiro, M. A. Arcari, and M. V. dos Santos. 2015. Bovine subclinical intramammary infection caused by coagulase-negative staphylococci increases somatic cell count but has no effect on milk yield or composition. J. Dairy Sci. 98:3071-3078.

Wever, P. U., and U. Emanuelson. 1989. Effects of systematic influences and intramammary infection on differential and total somatic cell counts in quarter milk samples of dairy cows. Acta Vet. Scand. 30:465-474. 